\title{
Servant Leadership Styles: A Theoretical Approach
}

\author{
Thanh Nguyen Hai ${ }^{1 *}$, Quang Nguyen Van ${ }^{1}$ \\ ${ }^{1}$ Ho Chi Minh National Academy of Politics, Hanoi, Vietnam \\ ${ }^{2}$ Ho Chi Minh National Academy of Politics; Academy of Politics Region III, Danang, Vietnam
}

\begin{abstract}
The main objective of the article is to examine the leadership style through a number of analyses, evaluations and researches from available sources, in order to discover suggested facts related to leadership activities through the prisms of servant leadership theory. So far, many leadership theories have been developed, proposing different leadership styles. One of the most discussed leadership styles is the servant leadership, which implies that a person must be human first, leader second. Every leader must whole heartedly serves an organization to which he/she belongs. This is both an honor and a great responsibility for the leader. The main methods used in the article are analysis, synthesis, evaluation based on literature review. The article aims to point out the outstanding strengths of the servant leadership style that a leader needs. The article focuses on specifying the strengths in servant leadership that leaders need in the current context of ever changing world, and hence, proposes guidelines for leaders to learn and practice so that they can better serve their public organizations.
\end{abstract}

\section{Keywords:}

\section{Leadership;}

Theoretical Research;

Servant Leadership Style;

Article History:

$\begin{array}{llll}\text { Received: } & 21 & \text { January } & 2021 \\ \text { Revised: } & 16 & \text { March } & 2021 \\ \text { Accepted: } & 23 & \text { March } & 2021 \\ \text { Published: } & 01 & \text { April } & 2021\end{array}$

\section{1- Introduction}

There are many ways to classify leadership styles: leadership based on trait theory -personality, and cognitive qualities help a leader succeed in leadership; theory of skills - knowledge and skills to be an effective leader; case theory - a specific situation to determine the applied leadership style; contingency theory - leadership effectiveness depends on appropriate leadership styles for situations; goal theory - the path, the leader's ability to inspire, share with subordinates to achieve the desired goal; transaction theory, focusing on communication and setting expectations for leadership outcomes; transformation theory, discussing the ability of leaders to engage and connect with subordinates so that they achieve maximum results, and servant leadership theory - leaders as the first servant, who leads and generates motivations for the development of the organization [1]. However, the article will focus on analyzing and interpreting issues around servant leadership, an issue that has gained attention in recent years, because it is believed to be capable of creating positive results.

Never before has the discussion of serving leadership styles been the focus of the current broad discussion of leadership styles. There are many potential reasons why the world is in a leadership crisis. On the other hand, leadership has become increasingly difficult, complex, and multifaceted for organizations of all types around the globe, thus posing new questions and challenges related to identifying the type of leader is the most suitable, but in fact this is extremely difficult in the context of the fast changing world, unpredictable developments, the leadership style has become very effective [1]. However, according to Gandolf [2] up to now, the servant leadership style has appeared for more than 40

* CONTACT: Thanhhaitlh@gmail.com

DOI: http://dx.doi.org/10.28991/esj-2021-01273

(C) 2021 by the authors. Licensee ESJ, Italy. This is an open access article under the terms and conditions of the Creative Commons Attribution (CC-BY) license (https://creativecommons.org/licenses/by/4.0/). 
years, but the majority of publications on leadership claim that this style is likely to cause the most misunderstandings in research on leadership styles.

Many opinions suggest that from being a servant to being a leader and how a leader can become a servant, this seems difficult to accept [3-5]. Some opinions suggest that the humility, meekness of a leader in servant leadership style is considered weak or ineffective in a social environment without democracy, the rise of the master. In the individual sense, modesty, collectivism, and the sharing of power are not appropriate [6] However, the presence of the receiver as a servant also received support from Kiechel [7]. DePree [8] agrees with Kiechel's view that leadership and service are synonymous, first must be in the position and position of the servant. Leadership-style leaders serve not to let things go their own way, but actively intervene [9]. Ever since Greeleaf published servant leadership style theory, more and more documents emphasize the leader as servant, proving its influence and effectiveness on development of society. Serrano [10] suggests that with a significant increase in leadership in the present context, servant leadership styles are becoming more common and applicable to leadership differences between cultures. Hoch [11] presented empirical evidence of the growing effectiveness of leadership in a different leadership approach compared to other leadership methods, which demonstrates the superiority of leadership style become more and more popular in leadership.

In the context of renewal and far-reaching international integration, especially in developing countries, research on servant leadership style has an important meaning, representing the ideas that "the root of a country should be the people" and the leader should be a servant of the people [12], that the leader must do whatever is beneficial to the people and avoid whatever is harmful to the people [13], the leader assuming any position in the public sector, first and foremost, should love the people, put the interests of the people above all else, and have the spirit of impartiality [14]. Therefore, servant leadership is becoming a common leadership style, which brings success to the leader and enhances development for the public sector.

If the goal is to understand the outcome of leadership and different leadership styles, especially leadership in the public sector is to first clarify what is a servant leadership style? and why it has become so important, contributing to the current success and development of the leaders, the discussion on the direction of applying the servant leadership style. On that basis, the structured article is, first of all, the concept of servant leadership style, the challenges posed when building leadership style serving the public sector, which include: In the general context, challenges arise in building leadership styles that serve the public sector and building leadership styles that serve the public sector.

\section{2- Design Research and Reasoning}

A servant leadership style is becoming increasingly popular and can enable leadership to adapt in many different cultures [10]. On the other hand, leadership style can be seen as a comprehensive leadership method that attracts followers in many aspects of establishing positive relationships, ethics, emotions, spiritual values, and stars empowered subordinates to develop their own abilities on the basis of the leader's direction, altruism, and morality as expected. A servant leader begins with the natural feeling that one wants to serve more than before, gradually leading a person to aspire to be a leader [15]. A leader must first serve society no matter where they are and through that interaction will be naturally recognized as a leader, but the serving leader can be subtle so that everyone Everyone can see the results of leadership [16]. A servant leader must always have humility, eyesight accompanied by a willingness to learn [17]. Since Greenleaf's servant leadership theory emerged, the number of studies focusing on server leadership has increased exponentially [18]. Koch [19] affirms that servant leadership is a leadership method, Manning [20] argues that servant leadership creates a resonance of the values of belief, this style emphasizes efficiency through empowerment. For individuals, Crippen [20] analyzes the role of servant leaders in inclusive education, Omoh [22], on the presence of servant leaders as public university presidents, Irving và Longbotham [23, 24] analysing leadership effectiveness of servant leadership styles, Dingman [25] studies the role of servant leaders in planning for leadership, Stephen [26] conducts a test on public university presidents' perceptions of servant leadership and affirms leadership as a successful leadership style, university rectors. All academics advocate for leadership that serves as a successful style of leadership for universities.

Therefore, the article is based on a set of research papers, a system of published articles on leadership and leadership to identify different aspects of servant leadership styles [27] to build the theoretical basis and come to define a servant leadership model [28]. The main focus is on using resources from Web of Science databases, Scopus, sources from Google Scholar, Researchgate. The review process shown in the figure below is based on the views of the author Sojka and Lepšík [29]. We believe this rationale is very important for understanding and modeling leadership style serving the public sector, especially in least-developed and developing countries where leaders need innovations in leadership styles, applying leadership theories to promote development of public organizations. 


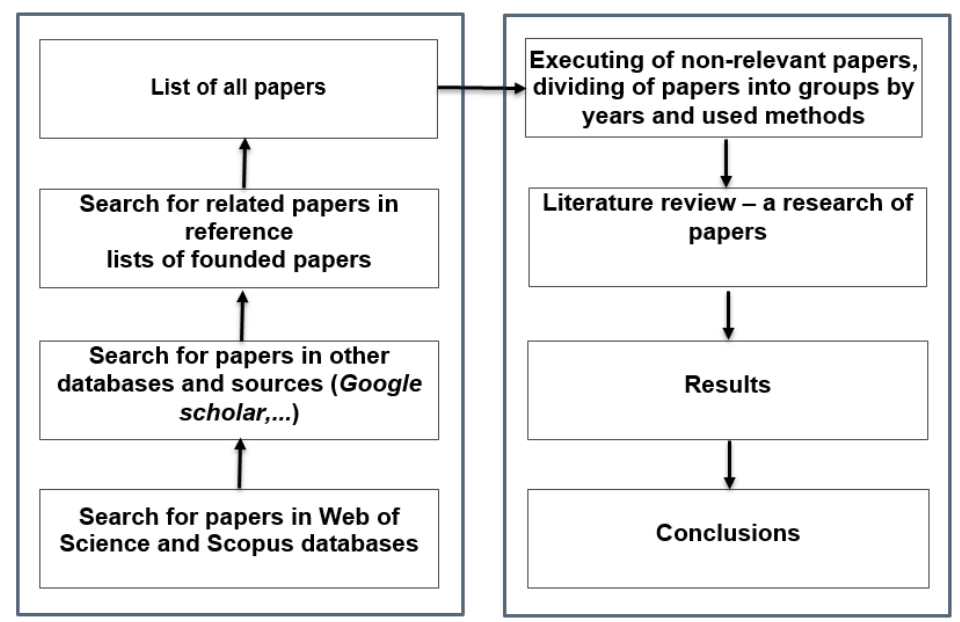

Figure 1. Flowchart of the literature review procedure [29].

\section{3- Servant Leadership Style}

The servant leadership style emerged from the ancient monarchy with widespread recognition that leadership was to serve people and the country [4]. However, it was not until 1970 that the term leadership style was formally introduced in Greenleaf [30] study. Up until now, the servant leadership style is an increasingly popular concept in leadership research, seen as a holistic approach to work, a sense of community and power sharing in leadership decision-making [30].

Theo Greenleaf [15] the servant leader facilitates goal achievement by giving team members what they need to be effective. When practicing a servant leadership style, the outcome of leadership can be stubbornly slower than practicing another style, even though employee engagement is higher, it focuses on success the success of the individual mission, the servant leader leading the staff, collectively and their team to achieve their leadership goals [9] but sustainable results because employees are inspired and they know who they are serving, for what motivates them and so it creates human cohesion. Employees with employees, employees with leaders and connecting people to the job, because they have common ideals, common goals. So far, there are many studies that have shown that the servant leadership style creates a very positive psychological effect on the employee, the servant leader has filled this gap by building a sense of social identity among their followers [32-34] servant leadership style has a positive effect on team performance [35, 36], servant leadership style also has a positive effect on the organization's work performance [37].

Many studies try to come up with their own model to measure servant leadership style, asserting that servant leadership is leading, empowering employees. Among these studies propose a six-dimensional servant leadership model, that is: voluntary dependence, authentic self, covenant relationship, responsible ethics, spiritual transcendence, influence conversion [38]. Liden [39] proposes a seven-dimensional model that includes empowerment, helping subordinates grow and succeed, putting subordinates first early, emotional healing, conceptual skills, creating value for the community and ethical conduct. Van Dierendonck's eight-dimensional model Van Dierendonck [40] includes empowerment, humility, support, authenticity, forgiveness, courage, responsibility, and management. Wang [41] presents an eleven-dimensional model in Chinese content, respect for employees, care for employees, helping subordinates develop and succeed thoughts of desire, ease of approach, willingness to sacrifice, carefree and honest, pioneering spirit, providing guidance to employees on work, social responsibility and empowerment.

According to Eva et al. [42] modern definition of servant leadership focuses on the motivation, regime and thinking of the leader. First, the leader's motivation is to be directed towards others and away from a sense of self-direction, the notion that this leadership style is highly altruistic. Second, the servant leadership approach specifies that the leader recognizes that followers are individuals with distinct needs, limitations, and goals and that they should be encouraged to develop into the best version of themselves surname. Third, servant leadership is found when leaders take the needs of the larger community, beyond their own organization, into account when making decisions. Using this definition, servant leaders focus on a broad range beyond themselves, use a high level of engagement with followers, and genuinely care about the well-being of the community. This conception allows for further study of the concepts of leadership with two prisms: characteristics that define servant leader (for executors) and servant leadership theory (for researchers).

A servant leadership style focuses primarily on the development and well-being of employees and associates where they belong, shared power in leadership decision-making, while traditional leadership is often associated with the accumulation of experience and the exercise of power in a person as a leader. Servant leadership shares power, sets the needs of others into common values, helps people grow together and creates the highest commitment to achieve the organization's common goals. 


\section{4- Challenges Posed when Building Leadership Styles Serving the Public}

Slow and developing countries have achieved a number of remarkable achievements, which can be seen through the vivid reality in many countries when there is an innovation in leadership style of the team of leaders at all levels. With the change in leadership styles from ruling, authoritarian, bureaucratic, paternalism to new leadership styles, many countries have quickly turned from the poorest countries in the world into low average entry. For example, in the case of Vietnam, from 2002 to 2018, GDP per capita increased by 2.7 times, reaching over $\$ 2,700$ in 2019 , with more than 45 million people out of poverty [43]. Despite its impressive achievements, Vietnam is still fundamentally a purely agricultural economy, with the majority of the population living in rural areas with low levels of development [44]. The situation of falling back into poverty tends to increase, especially in remote and mountainous areas, areas inhabited by ethnic minorities, and areas often hit by natural disasters and epidemics; In the education sector, the curriculum and learning content is both overloaded and out of date; The structure of the training profession is not balanced, the teaching and learning methods are old, the quality of the trained human resources is generally low, not meeting the requirements of accelerating industrialization and modernization; In the field of people's health care, the health network has been expanded, but the equipment is inadequate, unreasonably distributed, not convenient for the people; Many social problems are painful due to the weak management role of the State, the lack of discipline in the country, and complicated corruption [45].

In building the legal corridor, the organizational structure still has many inadequacies. The burdensome bureaucracy, a large but effective and efficient civil servants in dealing with weak work not only burdens the national budget, but also creates conflicts of interest and power struggles. causing internal disunity, creating negative consequences affecting the reputation and honor of agencies and organizations, one of the reasons can be mentioned as authoritarian leadership style, patriarchal style, leadership style bureaucracy is used overly necessary [46]. In fact, the role of state management by administrative orders based on a detailed system of ordinances and ordinances imposed from top to bottom is still quite popular in the world, especially in least-developed and developing countries. Therefore, authoritarian style, patriarchy, administrative order mechanism, even discipline and discipline are popularized, this is also the main cause of ideological deterioration. The politics, morality and lifestyle of a part of the leadership have not been pushed back, present, some still have more sophisticated and complicated developments; corruption, waste, and negativity are still serious, focusing on the number of leaders in positions in the state apparatus [47]. It is time to standardize, tighten discipline and discipline in parallel with institutional building, creating environment and conditions to promote innovation, promote creativity and protect cadres who dare to think, dare to do and dare breakthroughs for the common good. Assignment and decentralization are associated with delegation of rights and binding responsibilities, and at the same time enhancing inspection, supervision, power control and strict handling of violations [48]. In the context of many challenges and difficulties as mentioned above, countries need to aim to build a democratic society, discipline, consensus, justice, civilization, citizen awareness, and law compliance [49]. To achieve equality, progress, real democracy in society, one of the necessary leadership styles, creating intimacy, trust, tolerance between leaders and supporters is the servant leadership style.

Public sector leadership with several highlights of which greater control and stakeholder engagement leads to high accountability; high formalization; motivation to serve the common good is high, focusing more on the common good [50]. Therefore, there is complexity and ambiguity about the goal; the leader is sometimes not competent enough to eliminate, hire, promote or determine employee salaries or these are often delayed; There is a strong emphasis on overall job satisfaction over positions [51] and leadership in the public sector always emphasizes the mutual benefits of society, sacrifice, and responsibility. Responsibility and integrity [52] Public sector leaders face more accountability and control of stakeholders [53], and at the same time they often face performance pressure [54].

Hai and Giang [55] firstly, public sector leaders are facing growing social challenges. For example, in countries with developed economies such as the US, Japan and many European countries that are facing many difficulties with an increasing proportion of the aging population, many developing countries such as Vietnam, China, India ... are facing the challenge of developing the quality of social human resources. On the other hand, the leaders of the public sector have to deal with that to ensure fairness, social equality, and conflicts in terms of needs of different social groups. Second, attracting and ensuring the participation in state management of citizens and social organizations is increasingly high, requiring a change in public sector leadership thinking and philosophy. Leaders are faced with the demands of giving real ownership to the people instead of simply trying to serve them and ensuring the greater role of social organizations in decision-making allocating resources and administering public policies. Third, public sector leaders are increasingly asked for increased transparency and accountability, meaning there is a higher, tighter oversight from the media and the public, and public leadership. Mission is fairness, accountability and transparency in all public domain endeavors. Fourth, public sector leaders are expected to maximize the use of information technology to increase the provision of important public services to the people in a convenient, inexpensive and efficient manner. Therefore, it must be determined how advancements of technology such as big data, artificial intelligence, and e-governance can be applied to the performance of government agencies. Fifth, the requirement for leadership in the public sector needs to build its own knowledge base, because the lack of knowledge of modern public leadership will cause deadlock in leadership and governance public [56]. 
In addition, the capacity of the staff in many countries is currently uneven, many officials, including high-ranking officials, lack professionalism, do not work in the right profession, forte. Many young officials lack bravery and are afraid to practice. A part of cadres faded into their ideal, decreased willpower, worked superficially, was afraid of difficulties, afraid of suffering, deteriorated in political thought, morality and lifestyle. In the coming years, the regional and world situation will continue to have complicated and unpredictable developments, the explosion of the industrial revolution 4.0, the strong development of the knowledge economy, the development, global communication information, cyber warfare etc. requires a truly representative generation of political, ideological, capable of inspiring, grasping, comprehensively observing the developments of the times, know how to listen to the common voice of the people, must be exemplary examples of ethics and talent [57] while the system of training and retraining leaders is not consistent, professionalism is limited [58] During the operation of the state administration, some leaders are slow to innovate their thoughts and actions, do not want to change, want to maintain the current state to operate agencies and units according to subjective wishes individuals, creating certain buckles with the situation "hot and cold" in compliance with the laws of the State. Some leaders have not fully updated their knowledge of public administration. Some officials have deteriorated in morality, weak professional capacity, causing serious consequences, even leaving the principle and purpose of the public agency as "public servant and servant" of the people, who is entrusted by the people, empowered to serve social life [46].

The consequences of small production make narrow vision, arbitrary style, poor sense of organization and discipline, giving rise to individualism in the few leaders. When developing a multi-sector economy, the flip side of the market mechanism affects ideology, awareness, stimulates pragmatic lifestyles and opportunities; the bossy situation makes a part of leaders separate from the masses and does not care about the wishes of the people, reducing the effectiveness of state management and the people's confidence in the State [58]. In the context of opening up and developing a market economy, a leadership division still has weaknesses in political thought, morality, capacity and lifestyle, especially the leadership style that reveals many shortcomings. There are still leaders who have not been tested and trained, their behavior is slow, bureaucratic working style, far from the people, not adapting to the conditions of the market mechanism, so lack of initiative and being surprised by the situations. New leadership needs to be addressed [59]. On the other hand, the perception of industrial revolution 4.0 of a leadership division is not really complete and profound. Leadership style in performing administrative jobs according to existing models and regulations, no breakthrough and improvement thinking to change the ways and working methods to improve quality, effectiveness and efficiency State management activities [60].

\section{5- Build Leadership Styles Serving the Public Sector}

The basic characteristics of leadership style serving the public sector are empowerment and human development, leaders always look for, show humility, honesty, consider people as the greatest asset of the team organization, providing direction and being an inspiration, working hard for the common good [61]. To be a leader requires a leadership culture so that with the humanity, the spirit and a sense of service and the drive to lead, there are also personal qualities in which moral values must be considered. Center, thereby defining the characteristics of servant leadership styles: empowerment, enabling employees to develop, modesty. These characteristics of the servant leader positively affect respect, loyalty, a positive psychological environment, trust in fairness as well as can create commitment, satisfaction, the employee's engagement with the organization, improving the citizenship of the group, the team's work efficiency as well as maintaining the sustainability of the organization [62] (Figure 2).

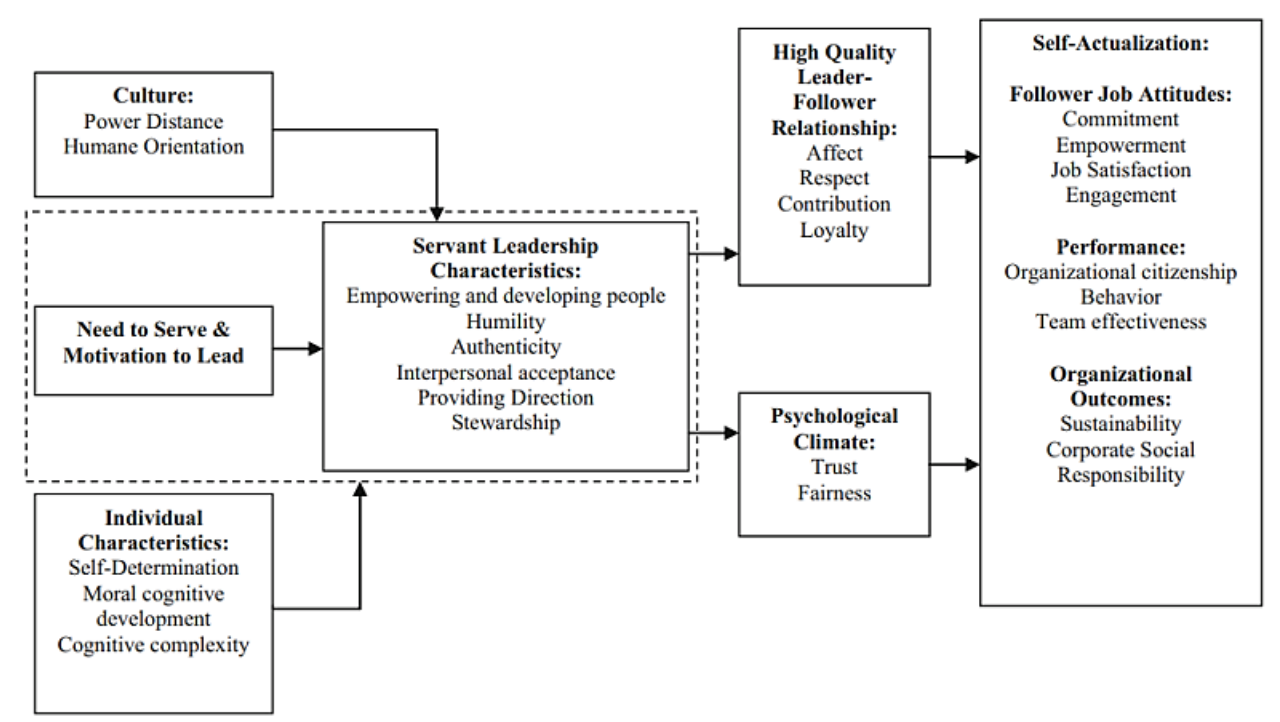

Figure 2. Conceptual model of servant leadership [62]. 
A servant leader must also have the traits Spears [63], which are a set of ten of key importance, are central to practicing the servant leader's leadership style: listening, empathy, healing, awareness, persuasion, conceptualization, foresight, stewardship, commitment to the growth of people, building community (Figure 3).

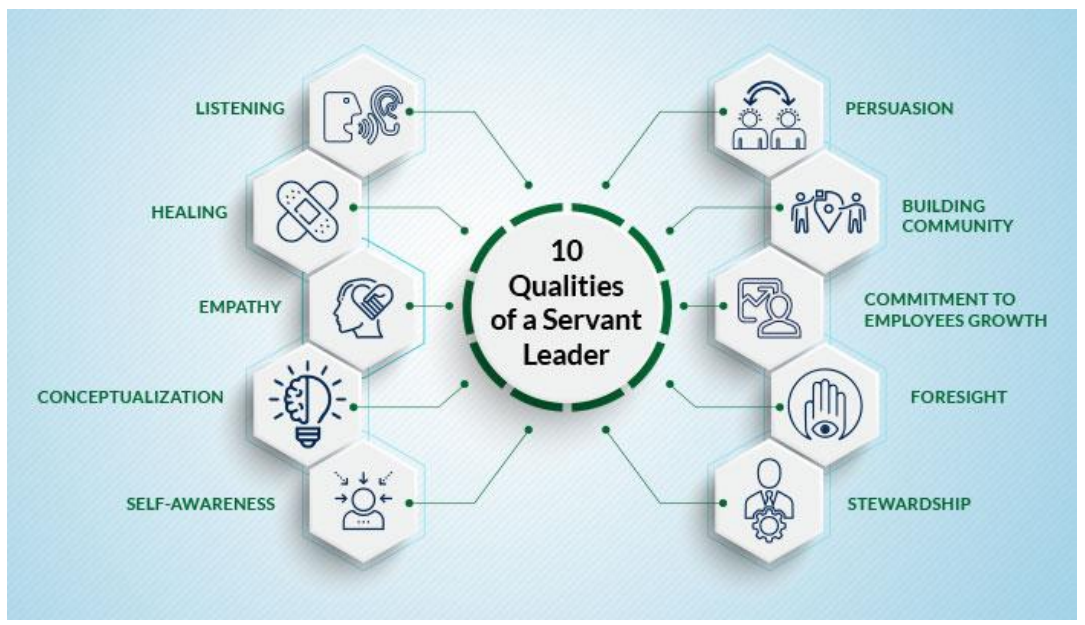

Figure 3. Ten characteristics of a servant leader [63].

Leadership in the public sector is also one of the Nuru's concern, seeking to attract and develop trustworthy, fair and authentic leaders to create a world free of injustice. On that basis, the Nuru developed a servant leadership framework with expectations and guidance for the formation of leaders for Kenya and Ethiopia [64] (Figure 4).

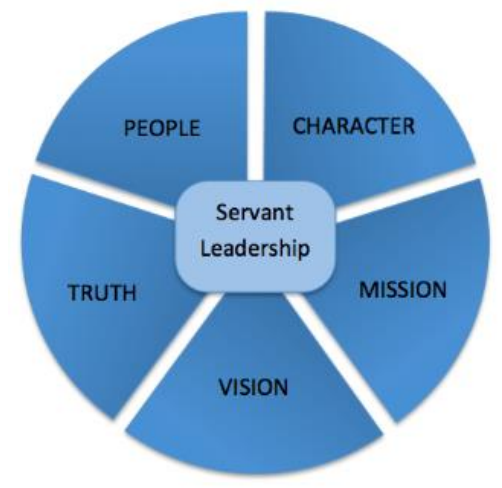

Figure 4. Servant leadership at Nuru [64].

Nuru's model of servant leadership emphasizes five core values: People, putting others' needs ahead of theirs. Personality, gaining respect from the people they lead as well as from stakeholders. The mission, the leader, is motivated by a mission to accomplish good outside of themselves. The vision inspires others to see the better world as possible and is motivated by being a part of its creation. Truthly, transparency in how a leader demonstrates leadership. The mission of ending extreme poverty requires a leader who has a spirit of service and inspiration to form a better humanity and society [64]. These views are good suggestions and can completely apply to building leadership styles serving the public sector in some nations in the context of innovation, integration process with the world out changing quickly, towards building a good society for the goal of a rich people, a strong country, a democracy, equality and civilization.

Servant leadership has long been formed in the traditional values of the public sector, which is a people-centered administration [55], with solutions: First, build and apply a competency framework for the leadership team. Author group Quan [65] and colleagues built a leadership capacity framework for the public administration sector with 6 groups of competencies: public ethics; local knowledge capacity; professional capacity; executive management capacity; human resource management capacity; self-management capacity; Second, changing the way of finding and selecting public sector leaders, practical competencies are seen as more important criteria than qualifications; Thirdly, to develop the capacity of leaders in the public sector through training and retraining activities to really become servant leaders; Fourth, public sector leaders need to nurture and promote the realization of core public sector values; Fifth, remove barriers about the old culture of public management and the thinking of innovation. The public sector is making efforts to change from a culture of "rule" to "servant". Administrative servant culture refers to democratic administration, rule of law, responsibility and serving citizens as the principle of operation [55].

Minh [66] has raised 6 styles of servant leaders: 1) Using power honestly, using leadership and power lawfully for the common good of who they served. They see leadership as a means of achieving common goals, not personal gain. 
2) Understand the importance of everyday details to make members feel interested in work. 3) Listen and care to the members of the organization, willing to take the time to listen to others, actively seek opinions and ideas from members to form a relationship of respect each other so that the servant leader will understand the members' sincere thoughts and aspirations, helping their members achieve their wishes. 4) Promoting members' abilities, helping members see their abilities, helping them do things they can but never thought of by setting them possible goals and challenging. 5) Inspire others to serve the same job, the servant leader knows they cannot do it alone. 6) Always adapting to suit the situation, they are not the best at everything, but they know their strengths and weaknesses to gradually adapt and overcome all situations that arise in the best way.

According to Hoanh [67] how to measure the best servant leadership is that the person served has the opportunity to develop well his / her abilities? When served, can they have more freedom, greater independence, those served have the potential to become a servant in the future? How does leadership style affect the underprivileged in society? Do they get anything or at least not be taken away?" Today, people often use the image of Jesus washing the feet of his disciples or Mother Teresa helping the poor on the streets as a symbol of servant leadership. In the face of leadership challenges, servant leaders need to have a close, open, listening attitude and seek to persuade, close with employees so that they can find support, trust the leadership style effective new servant [59] It's time to change from bureaucratic leadership, administrative imperative, autocratic leadership to be eliminated in a democratic society, rule of law, leader becomes servant, actively practice servant leadership styles [68]. Thao [69] thinks that servant leadership style is a combination of a behavior system based on four elements: improving personnel, the leader always prioritizes personal development and personal professionalism. members, making sure everyone has a background of professional knowledge and skills, their actions motivated by a genuine desire to help others; Create trust for employees by honesty in words and actions; values community over themselves, taking everyone's development first, always wanting to help rather than controlling others, and willing to share power if it encourages growth and brings success for supporters, always putting the interests of others over yours; listen and respect, trust with employees.

Regulation No. 89-QD/TW dated August 4, 2017 of the Central Committee of the Communist Party of Vietnam on the title criteria framework, the orientation of the criteria framework for the assessment of leaders and managers at all levels as stated clear the standards of the leader: About ideological politics; morality, lifestyle, sense of discipline; capacity and prestige must meet the practical requirements of Vietnam's national reform and international integration [70]. Decree No. 90/2020/ND-CP of the Government of Vietnam [71] on assessing and grading the quality of cadres, civil servants and public employees has raised 5 criteria, including: Politics; morality, way of life; working style and style; sense of organization and discipline; results of performing assigned tasks and duties.From the theoretical basis and generalizations from the above-mentioned studies on servant leadership style, we raise the model leaders serving the public sector in Vietnam with 5 expressions: Political thought; morality, way of life; working style and manners; sense of organization and discipline; results of implementing assigned functions and tasks (Figure 5).

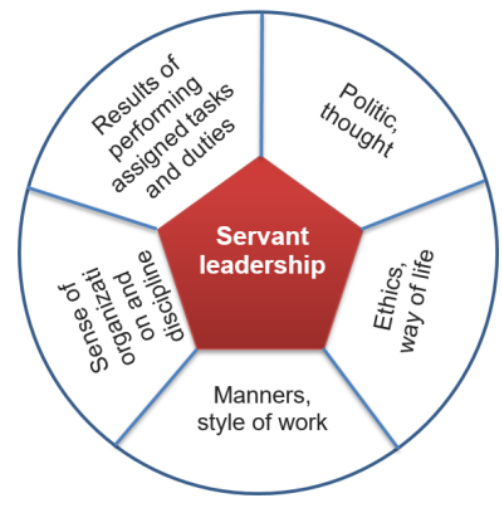

Figure 5. Leadership style model serving the public sector.

1) Political ideology: Strong political stance, opinion, and bravery, putting the interests of the nation, the people, and the collective above the individual interests, constantly striving for virtue [70]; Do not waver before all difficulties and challenges [71]; Form a sense of public service associated with the development goals of the unit, locality and country; Building a team of leaders who are enthusiastic, aspirational to dedicate, work to promote the innovation cause of the country [60]

2) Ethics, lifestyle: Pure ethics, honest lifestyle, humility, sincerity, simplicity, dedication and responsibility for work, integrity, always striving to build solidarity, be exemplary, responsible to colleagues. No embezzlement, corruption, no manifestation of moral deterioration, especially not letting relatives and acquaintances take advantage of positions and powers to make profits [71]. For the people, the role model is at the forefront of all work, attentive and consistent in thought and action, exemplary in training revolutionary morality, diligent practice, thrifty, integrity, righteousness, fairness. In order to become dedicated public servants of the people, 
the leader must be truly close to the people, understand the people, day and night concerned with the interests of the people, must be truly for the people serving [72]. Especially, leaders at strategic level must wholeheartedly serve the Fatherland, serve the people, and benefit the people, the Fatherland and the nation; not doing anything harmful to the country and the people; taking the warmth, happiness and satisfaction of the people as the target to strive. It is truly the nucleus of unity, gathering, motivating and promoting collective intelligence, at the same time having to dare to think, dare to do, dare to take responsibility for the interests of the nation - the Communist [73].

3) Working manners and styles of working: Capable of detecting conflicts, challenges, opportunities, advantages, new problems, difficulties and limitations and shortcomings in practice, boldly proposing tasks appropriate, feasible and effective services and solutions to promote, promote or disassemble. Industrious, hardworking, dynamic, creative, dare to think, dare to do, dare to take responsibility and for the people to serve. Exemplary, capable of gathering and promoting the synergy of collectives and individuals, who are being trusted and trusted by the people. Truly typical of revolutionary morality, political bravery, intelligence, clarity, exemplary in all aspects. At the same time, it also actively gives opportunities and focuses on staff development, guides and helps individuals in the organization to develop, always has a spirit of cooperation in work [74].

4) Sense of organization and discipline: obeying the organization's assignment, honesty [71]. With staff at strategic level, they must be really typical in politics, ideology, competence and prestige. In addition, the armed forces must have absolute values of loyalty to the Fatherland and the people, ready to fight and sacrifice for the independence and freedom of the Fatherland, for the happiness of the people, and to be strict in the sense of discipline organization [74].

5) Results of implementing assigned tasks and responsibilities: proactively preventing and combating corruption and waste. Scientific, democratic working method. Actively implement the reform of civil service regimes and civil servants within agencies and organizations [71]. Each leader must actively implement strictly their own regulations, regulations and commitments [74] Moreover, it is necessary to develop a mechanism to motivate and encourage leaders to successfully complete their tasks and have a mechanism to eliminate and dismiss those who have not completed their tasks, violate discipline or lose credibility with the people [75].

Currently, the servant leadership style is considered as the ideal style of leadership amongst many senior leaders in the government, in corporations, large corporations of the State, in the public sector, this style is also especially prevalent in charity and religious organizations [76], contributing adapting the organization to the rapid change of the current context when leaders are always faced with complex issues with high levels of risk [76], making the leader truly "public servant" of the people who is entrusted by the people and empowered to serve and manage social life [46]. Especially leaders serving the public sector always prioritize the development of all people, considering the human being the strategy of development, the human being the root of all jobs [77], all successes or failures are due to good or poor leadership [77]. Therefore, the leadership of the public sector is associated with the role of the leader, therefore, in the current leadership context, the servant leadership style should be seen and considered as a leadership style of high character in the public sector.

\section{6- Conclusion}

The process of training servant leadership to have leaders serving the public sector cannot happen overnight. This requires that each leader proactively changes his personal qualities to become more conscientious as a leader but also a dedicated service to the organization and the masses people. Serving leadership style is becoming more and more popular in the public and private sectors, contributing to building trust and loyalty from employees, encouraging employees to actively contribute to the development of the organization. Increasing employee productivity as they are empowered to be more proactive, as employees are encouraged to participate in all aspects of the leadership decision-making process through which they see responsibility, their role, to perform assigned tasks with independence, flexibility and feel excited, increase motivation when they feel they are appreciated from the leader. On the other hand, it can overcome the abuse of power because the decision-making leadership is a shared responsibility, the leader shares information, considering the solutions, the decisions, the employee's ideas will form the optimal solution, help agencies and organizations to fully access information resources through the lens of different perspectives.

To become a dedicated servant leader, a leader must always be aware of the servant culture, place the needs of the masses before their own needs, consider it as the top priority and increase cohesion in the organization, always being a listener and understanding, inspiring, attracting the participation and contribution of everyone, creating opportunities for employees, the masses to develop their capabilities and strengths. In particular, the working style of public sector leaders must always have the spirit of optimism and strong political courage even in the face of the harshest challenges. Always have an ethical, simple lifestyle, define people as an important factor to bring the prosperity of the organization, of the locality. With the promotion of the servant leadership style, the government and the people become closer, overcoming bureaucratic thought, administrative orders, the role of the people is promoted, the people know, the people 
discuss, contributing to the successful implementation of national renewal.

\section{7- Declarations}

\section{7-1-Author Contributions}

Conceptualization, T.N.H. and Q.N.V.; writing—original draft preparation, T.N.H. and Q.N.V.; writing—review and editing, T.N.H. and Q.N.V.; All authors have read and agreed to the published version of the manuscript.

\section{7-2-Data Availability Statement}

Data sharing is not applicable to this article.

\section{7-3- Funding}

The authors received no financial support for the research, authorship, and/or publication of this article.

\section{7-4-Conflicts of Interest}

The author declares that there is no conflict of interests regarding the publication of this manuscript. In addition, the ethical issues, including plagiarism, informed consent, misconduct, data fabrication and/or falsification, double publication and/or submission, and redundancies have been completely observed by the authors.

\section{8- References}

[1] Gandolfi, Franco, and Seth Stone. "Clarifying leadership: High-impact leaders in a time of leadership crisis." Revista de Management Comparat International 17, no. 3 (2016): 212-224.

[2] Gandolf F., "Fundamentals of leadership development, Executive Master's in Leadership Presentation," in Executive Master's in Leadership Presentation, Georgetown University, (2016).

[3] Russell, Robert F., and A. Gregory Stone. "A Review of Servant Leadership Attributes: Developing a Practical Model." Leadership \& Organization Development Journal 23, no. 3 (May 2002): 145-157. doi:10.1108/01437730210424.

[4] Sendjaya, Sen, and James C. Sarros. "Servant Leadership: Its Origin, Development, and Application in Organizations.” Journal of Leadership \& Organizational Studies 9, no. 2 (September 2002): 57-64. doi:10.1177/107179190200900205.

[5] Wong, Paul TP, and Don Page. "Servant leadership: An opponent-process model and the revised servant leadership profile." In Proceedings of the Servant Leadership Research Roundtable, Virginia Beach, VA, (2003):1-11.

[6] Mcfarlane, Donovan A. "Impressed and Inspired: Encountering Genuine Leadership with Dr. Barry Posner and Dr. Agueda Ogazon." E Journal of Organizational Learning \& Leadership 9, no. 2 (2011): 26-48.

[7] Kiechel W., "The leader as servant," in Reflections on servant leadership: Service, stewardship, spirit, and servant-leadership, New York, NY, John Wiley and Sons, (1995):121-125.

[8] DePree, M., Leadership Jazz, New York: Dell Publishing, (1992).

[9] Gandolfi, Franco, Seth Stone, and Frank Deno. "Servant Leadership: An Ancient Style with 21 st Century Relevance." Review of International Comparative Management/Revista de Management Comparat International 18, no. 4 (2017).

[10] Serrano M., "Servant leadership: A viable model for the Panamanian context?," Digital Dissertations International, vol. 67, no. 7, p. 173A. (AAT3228983), (2006).

[11] Hoch, Julia E., William H. Bommer, James H. Dulebohn, and Dongyuan Wu. "Do Ethical, Authentic, and Servant Leadership Explain Variance Above and Beyond Transformational Leadership? A Meta-Analysis." Journal of Management 44, no. 2 (August 31, 2016): 501-529. doi:10.1177/0149206316665461.

[12] H. C. Minh, Complete works, Ha Noi: National Political Publishing House, Vol. 15. (2011): 670.

[13] H. C. Minh, Complete works, Ha Noi: National Political Publishing House, Vol. 4. (2011): 65.

[14] H. C. Minh, Complete works, Ha Noi: National Political Publishing House, Vol. 4. (2011): 52.

[15] R. K. Greenleaf, "Servant Leadership: A Journey into the Nature of Legitimate Power and Greatness." Business Horizons 22, no. 3 (June 1979): 91-92. doi:10.1016/0007-6813(79)90092-2.

[16] MacKinnon, Joyce L. "Teacher as Servant: A Parable. Greenleaf RK. Newton Center, MA, The Robert K Greenleaf Center, 1987, Paper, 220 Pp, \$7.” Journal of Physical Therapy Education 3, no. 1 (January 1989): 46. doi:10.1097/00001416-19890100000011.

[17] Goodlad, J., Mantle-Bromley, C., \& Goodlad, S, "Education for Everyone: Agenda for Education in a Democracy." Choice Reviews Online 42, no. 03 (November 1, 2004): 42-1699-42-1699. doi:10.5860/choice.42-1699. 
[18] McIntosh, Timothy Alan, Justin A. Irving, and Bethel Seminary. "Evaluating the Instrumento de Contribucion al Liderazgo de Siervo (ICLS) for reliability in Latin America." Servant Leadership Roundtable at Regent University, Virginia Beach (2008).

[19] Koch C., "Servant leadership," America, vol. 191, no. 1, (2004):17-19.

[20] Manning B., "Firefighting servant leadership: The right medicine," Fire Engineering, vol. 157(5), no. 6, (2004).

[21] Crippen C., "Inclusive education: A servant-leadership perspective," in Education Canada, Vols. 19(4), 1045, (2005a).

[22] Omoh D. A. O., Analysis of servant leadership characteristics: A case study of a community college president, Vols. 68(4-A), 1550, (UMI No. AAI3262849), 2007.

[23] Irving, Justin A., and Gail J. Longbotham. "Servant leadership predictors of team effectiveness: Findings and implications." Proceedings of the American Society of Business and Behavioral Sciences 13, no. 1 (2006): 862-873.

[24] Irving, Justin A., and Gail J. Longbotham. "Team effectiveness and six essential servant leadership themes: A regression model based on items in the organizational leadership assessment." International Journal of Leadership Studies 2, no. 2 (2007): 98-113.

[25] Dingman W. A., "Servant leadership's role in the succession planning process: A case study," (2007).

[26] Stephen M. J., "Servant leadership: An examination of public school principals' perceptions of servant leadership as a successful leadership style," Dissertation Abstracts International, Vols. 68(3-A), 831, no. (UMI No. AAI3259618), 2007.

[27] Hart C., Doing a Literature Review, London: Sage, 1998.

[28] Gregory Stone, A., Robert F. Russell, and Kathleen Patterson. "Transformational Versus Servant Leadership: a Difference in Leader Focus.” Leadership \& Organization Development Journal 25, no. 4 (June 2004): $349-361$. doi:10.1108/01437730410538671.

[29] Sojka, Vladimír, and Petr Lepšík. "Use of TRIZ, and TRIZ with Other Tools for Process Improvement: A Literature Review." Emerging Science Journal 4, no. 5 (October 1, 2020): 319-335. doi:10.28991/esj-2020-01234.

[30] Greenleaf R. K., “The servant as leader," Servant Leadership", 1970, p. 1-338.

[31] Spears L., Insights on leadership: Service, stewardship, spirit and servant-leadership, New York, NY: John Wiley \& Sons, (1998).

[32] Van Dierendonck, Dirk, Daan Stam, Pieter Boersma, Ninotchka de Windt, and Jorrit Alkema. "Same Difference? Exploring the Differential Mechanisms Linking Servant Leadership and Transformational Leadership to Follower Outcomes." The Leadership Quarterly 25, no. 3 (June 2014): 544-562. doi:10.1016/j.leaqua.2013.11.014.

[33] Chen, Zhijun, Jing Zhu, and Mingjian Zhou. "How Does a Servant Leader Fuel the Service Fire? A Multilevel Model of Servant Leadership, Individual Self Identity, Group Competition Climate, and Customer Service Performance.” Journal of Applied Psychology 100, no. 2 (2015): 511-521. doi:10.1037/a0038036.

[34] Chiniara, Myriam, and Kathleen Bentein. "Linking Servant Leadership to Individual Performance: Differentiating the Mediating Role of Autonomy, Competence and Relatedness Need Satisfaction.” The Leadership Quarterly 27, no. 1 (February 2016): 124141. doi:10.1016/j.leaqua.2015.08.004.

[35] $\mathrm{Hu}, \mathrm{Jia}$, and Robert C. Liden. "Antecedents of Team Potency and Team Effectiveness: An Examination of Goal and Process Clarity and Servant Leadership.” Journal of Applied Psychology 96, no. 4 (2011): 851-862. doi:10.1037/a0022465.

[36] Schaubroeck, John, Simon S. K. Lam, and Ann Chunyan Peng. "Cognition-Based and Affect-Based Trust as Mediators of Leader Behavior Influences on Team Performance.” Journal of Applied Psychology 96, no. 4 (2011): 863-871. doi:10.1037/a0022625.

[37] Peterson, Suzanne J., Benjamin M. Galvin, and Donald Lange. "CEO Servant Leadership: Exploring Executive Characteristics and Firm Performance.” Personnel Psychology 65, no. 3 (August 2, 2012): 565-596. doi:10.1111/j.1744-6570.2012.01253.x.

[38] Sendjaya, Sen, James C. Sarros, and Joseph C. Santora. "Defining and Measuring Servant Leadership Behaviour in Organizations.” Journal of Management Studies 45, no. 2 (March 11, 2008): 402-424. doi:10.1111/j.1467-6486.2007.00761.x.

[39] Liden, Robert C., Sandy J. Wayne, Hao Zhao, and David Henderson. "Servant Leadership: Development of a Multidimensional Measure and Multi-Level Assessment." The Leadership Quarterly 19, no. 2 (April 2008): 161-177. doi:10.1016/j.leaqua.2008.01.006.

[40] Van Dierendonck, Dirk, and Inge Nuijten. “The Servant Leadership Survey: Development and Validation of a Multidimensional Measure.” Journal of Business and Psychology 26, no. 3 (September 3, 2010): 249-267. doi:10.1007/s10869-010-9194-1.

[41] Wang, C. X., Q. Ling, and X. J. Zhang. "The servant leadership scale design and inspection in chinese enterprise." Nankai Business Review 3 (2009): 94-103.

[42] Eva, Nathan, Mulyadi Robin, Sen Sendjaya, Dirk van Dierendonck, and Robert C. Liden. "Servant Leadership: A Systematic Review and Call for Future Research." The Leadership Quarterly 30, no. 1 (February 2019): 111-132. doi:10.1016/j.leaqua.2018.07.004. 
Emerging Science Journal | Vol. 5, No. 2

[43] The World Bank, "World Bank in Vietnam," $8 \quad 10 \quad$ (2020). Available online: https://www.worldbank.org/vi/country/vietnam/overview. (accessed 30 November 2020).

[44] Minh P. Q., "Vietnam 30 years of reform: Achievements, lessons and prospects," in International Workshop, Hanoi, For internal circulation only, (2016):11-16.

[45] Nam, P. X., "Overview of Vietnamese society in the process of reform for development and international integration," 2010. Available online: http://www.hids.hochiminhcity.gov.vn/c/document_library/get_file?uuid=3ddff82d-d4b4-4ab4-ad2b54b70d5469ee\&groupId=13025. (accessed 30 November 30).

[46] Phong, N. H., "Challenges in building public culture in our country today," (2019). Available online: http://lyluanchinhtri.vn/home/index.php/thuc-tien/item/2854-thach-thuc-trong-xay-dung-van-hoa-cong-vu-o-nuoc-ta-hiennay.html. (accessed 30 November 2020).

[47] VOV, "The full text of Central Resolution 4, Session XII on strengthening the party's regulation," 3110 2016. Available Online: https://vov.vn/chinh-tri/dang/toan-van-nghi-quyet-trung-uong-4-khoa-xii-ve-tang-cuong-chinh-don-dang-565179.vov. (Accessed 30 November 2020).

[48] Central Propaganda Department of the Communist Party of Vietnam, Paper on documents of the seventh conference of the XII Central Executive Committee, Ha Noi: Nxb Chính trị quốc gia - Sự thật, (2018).

[49] Prime Minister of Vietnam, "Decision No. 432/QD-TTg dated 12 April 2012 approving the Vietnam Sustainable Development Strategy for the period 2011 - 2020," Ha Noi, 2012.

[50] Orazi, Davide Christian, Alex Turrini, and Giovanni Valotti. "Public Sector Leadership: New Perspectives for Research and Practice." International Review of Administrative Sciences 79, no. 3 (September 2013): 486-504. doi: $10.1177 / 0020852313489945$.

[51] Rainey H. G., Understanding and Managing Public Organizations, San Francisco: CA:Jossey-Bass, (2003).

[52] Rooplekha Khuntia, Damodar Suar, "A scale to assess ethical leadership of Indian private and public sector managers," Leadership Quarterly, vol. 49, no. 1, (2004): 13-26. doi:10.1023/b:busi.0000013853.80287.da.

[53] Van Slyke, David M., and Robert W. Alexander. "Public Service Leadership: Opportunities for Clarity and Coherence.” The American Review of Public Administration 36, no. 4 (December 2006): 362-374. doi:10.1177/0275074006293628.

[54] Andersen, Jon Aarum. "Public Versus Private Managers: How Public and Private Managers Differ in Leadership Behavior." Public Administration Review 70, no. 1 (January 2010): 131-141. doi:10.1111/j.1540-6210.2009.02117.x.

[55] Hai Nguyen Thị Hong, Giang Hoang Vinh, "Applying leadership theory to building leadership in the public sector in Vietnam," (2020). Available online: https://www.bqllang.gov.vn/tin-tuc/tin-tong-hop/10056-van-dung-ly-thuyet-lanh-dao-phuc-vu-vaoxay-dung-doi-ngu-lanh-dao-trong-khu-vuc-cong-o-viet-nam.html. (accessed 25 November 2020].

[56] Radu, L. "How to develop Sustainable Public Administration Reforms," Transylvanian Review of Administrative Sciences, vol. 44 E/February, (2015):180-195. doi:10.24193/tras.

[57] Luu, K. "Building a contingent of cadres at strategic level - a key task of Party building in the current period," (20180. Available online: http://tuyengiao.vn/nghien-cuu/ly-luan/xay-dung-doi-ngu-can-bo-cap-chien-luoc-mot-nhiem-vu-trong-yeu-cua-congtac-xay-dung-dang-trong-giai-doan-hien-113821. (accessed November 11 2020).

[58] Tam, N. T. "Building a contingent of cadres and civil servants for the current administration in Vietnam," 2014. Available online: https://tcnn.vn/news/detail/6411/Xay_dung_doi_ngu_can_bo_cong_chuc_cho_nen_hanh_chinh_o_Viet_Nam_hien_nayall.ht ml. (accessed 29 November 2020).

[59] Duat, T. N. "Leadership and management style," Journal of Political Theory, vol. 11, (2013):78-81.

[60] Quan, T. V. "To build a contingent of Vietnamese cadres and civil servants to meet the requirements of the Fourth Industrial Revolution," (2020). Available online: https://tcnn.vn/news/detail/48854/Xay-dung-doi-ngu-can-bo-cong-chuc-Viet-Nam-dapung-yeu-cau-cuoc-Cach-mang-cong-nghiep-lan-thu-tu.html. (accessed 29 November 2020).

[61] Reddy, Asi Vasudeva, and A. V. S. Kamesh. "Integrating Servant Leadership and Ethical Leadership." Ethical Leadership (2016): 107-124. doi:10.1057/978-1-137-60194-0_7.

[62] Laub, J. A. "Assessing the servant organization: Development of the organizational leadership assessment (OLA) model," Dissertation Abstracts International, vol. 60 (2): 308A, no. UMI No. 9921922, (1999).

[63] Spears, Larry C. "Character and servant leadership: Ten characteristics of effective, caring leaders." The Journal of Virtues \& Leadership 1, no. 1 (2010): 25-30.

[64] Hong, T. "Why is servant leadership important to Nuru?," (2015). Available Online: https://nuruinternational.org/blog/ leadership/ why -is-servant-leadership-important-to-nuru/ (accessed 29 November 2020). 
[65] Quan, L. Competency Framework for Public Administration Leadership, L. Quan, Ed., Ha noi: Publishing House of Hanoi National University, (2016).

[66] Minh T. K., "HATE CHANGE," (2018). Available online: https://hatechange.org/lanh-dao-phuc-vu-dam-nhan-va-duy-tri-suphuc-vu/. (accessed 26 November 2020).

[67] Hoanh T. Đ., "OpenEdu," (2013). Available online: https://dotchuoinon.com/2013/01/20/lanh-dao-phuc-vu/?fbclid= IwAR0MZzeDG84o2QW20y9wx_g9IPBW2xW1fU5mN7A_9D4NAvvmEsX9Oxq5I6w. (accessed 27 November 2020).

[68] Duat, T. N. "Innovation Leadership style of leading cadres and managers in the national renewal period," Journal of Psychology, vol. 1, pp. 16-18, (2006).

[69] Thao H. P., "What is Servant leadership? Benefits servant leadership brings to businesses," 284 2020. Available Online: https://123job.vn/bai-viet/servant-leadership-la-gi-loi-ich-servant-leadership-mang-lai-cho-doanh-nghiep-794.html. (accessed 27 November 2020).

[70] The Central Committee of the Communist Party of Vietnam, "Regulation No. 89-QD/TW dated August 4, 2017 title standard framework, orientation framework of evaluation criteria for leaders and managers at all levels," Ha Noi, (2017).

[71] Vietnamese Government, "Decree No. 90/2020 / ND-CP dated August 13, 2020 on assessment and classification of quality of cadres, civil servants and public employees," Ha Noi, (2020).

[72] Ninh T. T. K., "Tuyen Giao," 112 2019. Available online: http://tuyengiao.vn/theo-guong-bac/hoc-va-lam-theo-bac-de-trothanh-nguoi-day-to-cua-dan-125625. (Accessed 29 November 2020).

[73] The Central Committee of the Communist Party of Vietnam, "Regulation No. 08-QDi /TW dated 25 October 2018 Responsibility to set the example of cadres and party members, first of all members of the Politburo, members of the Secretariat, and members of the Central Executive Committee," Ha Noi, (2018b).

[74] The Central Committee of the Communist Party of Vietnam, "Resolution No. 26-NQ/TW dated May 19, 2018 focused on building a contingent of cadres at all levels, especially at strategic levels, with sufficient qualities, capabilities and prestige, on a par with the task.," Ha Noi, (2018a).

[75] Communist Party of Vietnam, Document of the XI National Congress of Delegates, Ha Noi: National Political Publishing House, (2011).

[76] Dinh, P. B. "Training and fostering leadership and management skills for strategic-level officials," Communist Journal, (2018): 44-47.

[77] Minh H. C., Complete works, Ha Noi: National Political Publishing House, vol. (5), (2011). 